\title{
PLANNING SERBIA SPATIALLY - BUSINESS AS USUAL IN THE AGE OF INEQUALITY
}

DOI: https://doi.org/10.18509/GBP210467dj

UDC: 711.24:314(497.11)

\author{
Dejan Djordjevic ${ }^{1}$ \\ Nevena Vasiljevic ${ }^{2}$ \\ ${ }^{1}$ University of Belgrade, Faculty of Geography, Department of Spatial Planning -Serbia \\ ${ }^{2}$ University of Belgrade, Faculty of Forestry, Department of Landscape Architecture -Serbia
}

\begin{abstract}
Cities and regions in Serbia are increasingly taking ownership of their futures through the devolution agenda, yet deeper structural inequalities cannot be tackled by local action alone. National frameworks are needed, not least, given the lack of one for Serbia and, more generally, because of the sectoral approach which is taken to policy. In the first two decades of the 21th century, the spatial planning system in Serbia underwent a significant transformation following the general trends of change within the country. The predominance of the neoliberal - market model of the economy has directly led to the obvious suppression of social services both in quality and in terms of funding, and the same has happened with the environmental sector. To challenge the persistent social and economic inequalities across the State, in November 2019 the Spatial Plan of Serbia 2035 was launched, reaching in December 2020 the final draft status. Unfortunately, this national spatial framework become more the legal basis for massive infrastructure project rather then the comprehensive policy document, failing or carefully avoiding to address growing political, social and economic uncertainties brought by the global challenges of technological and climate change, beside the current pandemic. The paper analyzes the causal relationships that have led to the current state of planning, given the examples of spatial problem mitigation and relativisation, and discussed the effectiveness of such a partial approach to the field of spatial planning in Serbia.
\end{abstract}

Keywords: spatial planning, inequality, sectoral approach, Serbia

\section{INTRODUCTION}

Territorial development of Serbia is characterized by pronounced spatial unevenness which is the result of two opposite processes - on the one hand there is a concentration of population, capital, and activities in large centers, especially in Belgrade, and on the other hand emptying of rural areas and peripheral regions. The problem, of course, is not new and its solution was emphasized in all planning documents, including the Spatial Plan of the Republic of Serbia in 1996 and 2010.

The key determinants of these plans, especially the latter, emphasize the "competitiveness" of the territories in terms of access to different funds - which means that the neoliberal economic approach has not been abandoned, which implies inequality, sharp polarization in spatial terms, decline of peripheral regions in economic and social terms. etc.

The spatial plan of the Republic of Serbia from 1996 had as its basic starting point the socalled "Demetropolization of Serbia", i.e., reduction of development differences between Belgrade (and other large centers) and underdeveloped, i.e., peripheral regions (rural, 
hilly-mountainous, border, etc.). Thus perceived, the basic problem of the territorial development of Serbia has led to the fact that, in the best tradition of planning, measures, instruments and means are concentrated in the realization of a simple but important goal - balanced territorial development. Even after 2000, when the European contribution to the policies of territorial development began to be seriously respected, there was no reason to change the stated goal, following the best results of the socialist period, the concept of the so-called "Welfare state", which is widely applied in the areas we call the European Union today. Namely, many of the European recommendations, such as increasing accessibility or territorial cohesion, represent an adequate response to the problems in Serbia, but instead of using the European framework to give legitimacy to this, in principle, healthy policy, it went to the other extreme.

The general social, economic, but above all political environment pushed the planning in the other direction. In the programs of implementation of the Spatial Plan of the Republic of Serbia for the period 2011-2015 positive trends were observed in the selected indicators for all goals, with some restrictions. Particularly relevant for the assessment of the situation is the Report on the implementation of the Spatial Plan of the Republic of Serbia for the period 2016-2020. In the report for 2018 [1], the indicators for all goals are contradictory: when, for example. word on territorial cohesion, part of the indicators shows trends leading to increased cohesion, and almost the same number of indicators shows a decrease in cohesion.

The same is the case with the protection of the territory or regional connectivity. The only conclusion that can be drawn from this situation is that the 2010 Spatial plan of the Republic of Serbia is implemented partially, sectorally, without sufficient coordination of activities even within the same sector, which reduces the expected effects on space, especially in terms of very demanding sustainability standards.

Another assessment is particularly indicative [1] - by far the largest active implementation of strategic priority projects was recorded in the sub-area Sustainable development of economy, transport and infrastructure $(79.2 \%)$, and by far the weakest in the sub-area Population, settlements and social development (only 2,3\%). It is not difficult to conclude in which direction we should work in the new Spatial Plan of the Republic of Serbia.

\section{PHASE 1: THE INITIAL CONCEPT OF SOLVING SPATIAL INEQUALITY IN SERBIA}

When it comes to the differentiation of the space of Serbia, the Figure 1 is illustrative. The dilemma regarding the choice of scenarios was solved already during the preparation of the Thematic Notebooks: the presented solution was supported by an exceptional database and quality analysis [2]. The distinction between two zones and two dynamics of development, in the first variant called the core and the periphery, and in the later central part of Serbia and the border, hilly and mountainous, poorly accessible areas, is a scientific fact.

The initial concept of solving the problem of spatial inequality in Serbia is that the planning solutions will be adjusted in terms of different approaches to planning of both zones with implied planning measures and instruments to mitigate the obvious differences in terms of levels of development to the so called "acceptable unevenness" [3]. 


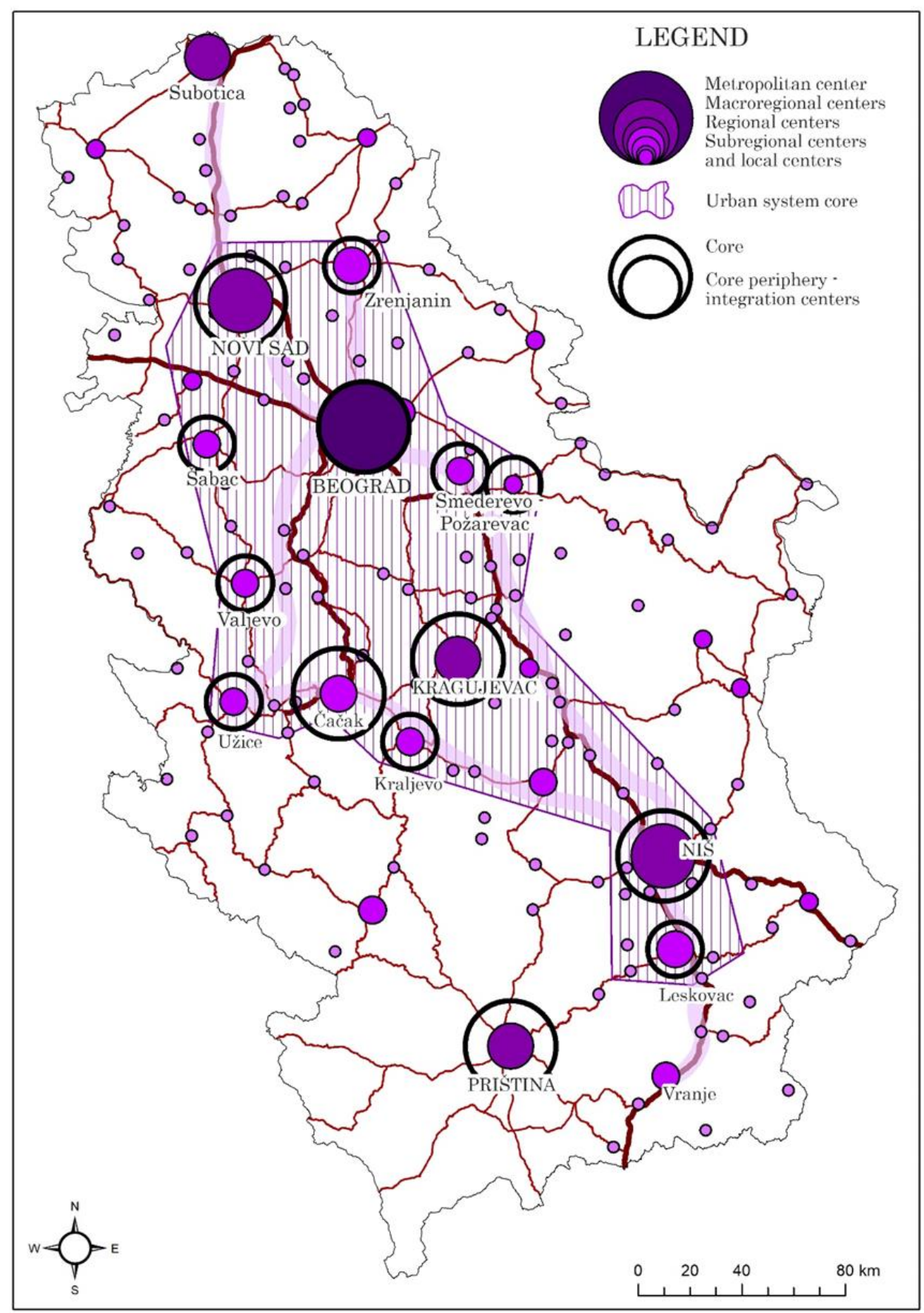

Figure 1. Spatial Development Dichotomy in Serbia: The "Core - Periphery" Concept [2]

With a large dose of generalization, it can be said that Serbia is a country in which, to a greater or lesser extent, the spatial-developmental dichotomy "core - periphery" (see: [4]) is expressed in all territorial-administrative and territorial-functional levels starting from municipalities - cities, through districts and larger regional associations to the state as a whole. Analyzes conducted for the purpose of reviewing the situation in the network of settlements in Serbia indicate the fact that, both in the settlement and in the socioeconomic sense, two insufficiently coherent and inconsistent units emerged, a core with a more or less coherent network of settlements and periphery which lacks that attribute. The differences between the core and the periphery are broken into transitional forms 
which, depending on the whole set of geographical, socio-economic, functional, administrative, and other characteristics, have different nuances and dimensions. Transitional forms form the semiperiphery, which is divided into fragments with the developmental intention of attaching to the nucleus and fragments that increasingly take on the characteristics of the periphery.

The core has the appearance of an irregular polygon, conditionally, limited by a line connecting Novi Sad, Zrenjanin, Požarevac, Jagodina, Niš, Kruševac, Kraljevo, Čačak, Užice, Valjevo, Šabac, Sremska Mitrovica, Novi Sad. North of the polygon is the influential sphere of Subotica, which will eventually join the core; in the southeast there is a tendency to integrate Leskovac, and to the southwest perhaps Pristina. The main, cohesive factor of the nucleus is its central part, which is truly fragmented, i.e.. divided into a highly urbanized part of the Danube-Sava development belt with the dominance of the influential spheres of Belgrade and Novi Sad, then into functionally urban areas of Kragujevac and Niš. A pericentral zone has been formed around the central part, which is differentiated into units of different levels of functional connection, socio-economic development, and integration with the center [2].

Within the core, there are "pockets" but also larger zones of underdevelopment in the form of smaller and larger enclaves affected by total depopulation, extensive agriculture, untimely substitution of industry based on outdated technology and management with a modern technological and management approach. and similarly. Almost all major cities in Serbia are located in the core (Table 1).

Table 1. Ratio of demographic sizes of the ten most numerous urban settlements in Serbia according to the 2011 Census [5].

\begin{tabular}{|l|l|l|l|}
\hline \multicolumn{1}{|c|}{ City } & \multicolumn{1}{c|}{ Population } & $\begin{array}{c}\text { Index based on } \\
\text { Belgrade population }\end{array}$ & $\begin{array}{c}\text { Index based on previous } \\
\text { city population }\end{array}$ \\
\hline Belgrade & 1.166 .763 & 1.000 & - \\
\hline Novi Sad & 231.174 & 0,197 & 0,197 \\
\hline Niš & 183.164 & 0,157 & 0,792 \\
\hline Kragujevac & 150.835 & 0,129 & 0,823 \\
\hline Subotica & 97.910 & 0,083 & 0,649 \\
\hline Zrenjanin & 76.501 & 0,066 & 0,781 \\
\hline Pančevo & 76.203 & 0,065 & 0,996 \\
\hline Čačak & 73.351 & 0,063 & 0,962 \\
\hline Novi Pazar & 66.527 & 0,057 & 0,907 \\
\hline Smederevo & 64.175 & 0,055 & 0,965 \\
\hline
\end{tabular}

In relation to the core, the periphery is spatially larger, affected by intensive depopulation, population decline in both rural and urban settlements, low degree of urbanization, demographic fragmentation of settlements, economic recession, etc. It is divided into segments, i.e. influential spheres of regional and subregional urban centers, which often do not overlap or touch.

The periphery of central Serbia is a typical example of a problem area. It is demographically empty and economically underdeveloped. A large part of it has a border position. It is characterized by traffic isolation, fragmentation and dispersion of agricultural areas and weak organization of agriculture, inaccessible market of agricultural products, occasional or constant decline in the role of mining and energybased genetics and metallurgy in population employment and economy (Bor, coal mines in eastern Serbia ... mines in western Serbia ...), traditional non-productive non-flexible industries, monostructural and non-diversified economy and the like (Bor, coal mines in 
Eastern Serbia, Western Serbia...) traditional production non-flexible industries, monostructural and non-diversionary economy etc. [6]. Also, underdeveloped human resources - unskilled labor force, unfavorable educational population structure that forms a barrier to new technologies and innovations in the economy, depopulation and the aging of the population and the like. This is especially true for border and spatially and economically isolated areas that are at great distances from significant development centers.

However, it should be emphasized that urban enclaves have also developed within the periphery, whose centers have development potentials, sufficient population size, relatively developed human resources and public social infrastructure, urban development continuity, cultural identity etc. This primarily refers to Vranje, Pirot, Zaječar and Bor in the Region of Southern and Eastern Serbia, and to Prokuplje, Novi Pazar, Prijepolje, Priboj, Loznica in the Region of Šmadija and Western Serbia [6]. Until the 90s of the last century, these cities were the regional poles of both demographic and economic growth with a pronounced function of work in industry.

Once presented to the working team in the analytical phase of the Plan development, this initial concept aroused enthusiasm so that other planning solutions could be built and defined on it. But that enthusiasm soon faded.

\section{PHASE 2: ABANDONMENT OF THE INITIAL CONCEPT - "NO ONE WANTS TO BE A PERIPHERY..."}

Regarding the concept of the Plan in general, after a continuous discussion, the idea prevailed that the Plan should concentrate on those statements that can be preformed within the planning system. The plan should be more physical and less integral. Therefore, you should stick to your spatial domain in accordance with the project task. That the Plan must have a focus, that is, a basic idea, which must be agreed upon, and that this idea must be formulated through clear goals, was not disputable. It is debatable where the focus of the plan will be. Through discussions and confrontation of different views, all under the impression of devastating demographic projections resulted in a (temporary) view that demographic recovery should not be the main goal of the Plan, but only an indicator, which must be taken seriously. The demographic deficit will dictate to a greater or lesser extent many planning solutions. When the concept of core - periphery was considered as a proposal for the focus of the Plan, there was an immediate negative reaction from the representatives of the relevant Ministry, which is the client and financier of the Spatial Plan. Their position was explicit: during the public insight, there will certainly be a negative reaction in the public because "... no one will be the periphery". This led to hesitation among the members of the working team: first, instead of a clear core-periphery concept, a milder euphemism was chosen for the central part of Serbia and border, hilly-mountainous, poorly accessible areas, and in the next phases of the Plan the initial concept was completely abandoned. Instead, the ordering party of the Plan explicitly requested that the spatial aspects of the Serbia 2025 Plan be incorporated into the text and maps of the Spatial Plan of the Republic of Serbia as a new focus [7], especially when it comes to building and modernizing infrastructure. It is likely that the network of state roads will be the main variable in defining the spatial development scenario, i.e., the Plan as a whole, if there are no significant objections to the public inspection in March 2021. The zones along the roads will represent the zones of faster development changes. With the increase of the distance from the corridor, the intensity of changes in space and development possibilities decreases, as well as the demographic 
potential. In that way, the criterion of increasing accessibility remained the only direct measure of mitigating spatial inequality in Serbia. As an indirect measure, there is a partial direction of spatial development at the local level through the land use plan, but given the weakness of local communities, it is a long-term and extremely uncertain endeavor [8].

Honestly, spatial accessibility has so far been one of the key dimensions of social development and public services, i.e. services of general / public interest. The ruling paradigm is that increasing the spatial availability of services in the field of social development reduces social exclusion, improves the quality of life and is one of the key factors in increasing social cohesion. In Serbia, however, the urban-centric model of public service organization has dominated for decades: 1) the basic criterion for organizing services is the number of users or population density, which results in public services being organized as a priority in urban settlements, without accompanying and complementary activities which makes them accessible also to citizens who do not live in these cities and to whom these services are not available in the place of residence (pupils and students' dormitories, mobile health services, mobile education services, mobile social support services, etc.); 2) models of organization of these services are adjusted to the cities (large facilities for a large number of users, stationarity, monofunctional facilities, lack of cooperation and joint programs of related services, high construction indices); 3) restriction of the right to use social protection services on the basis of land census (over 0.5 ha, regardless of the class / creditworthiness of the land); 4) services that are organized in rural settlements are, as a rule, substandard, of lower quality, in dilapidated and neglected buildings, not infrequently without basic installations (water, heating, sewerage); 5) the organization of public services follows the hierarchical position of the settlement (city) and its administrative-political function. The combined financing of public services from the republic and municipal budgets results in large differences in the funds for organizing public services [9].

In terms of innovative planning solutions, unfortunately, no progress has been made. It intends to confront the spatial aspects of social inequality and act with already seen and inefficient methods. It is indicative that it is an important idea to include zones of special interest in the Plan, of which almost all in the peripheral part of Serbia have also been rejected.

\section{DISCUSSION}

Thanks, to put it mildly, incoordination and the lack of a clear vision of territorial cohesion, socio-economic differences in Serbia are increasing. Leaving the social dimension in the conditions of transition, led to agglomeration in several large urban centers where the privatization of state-owned enterprises was more or less successful, especially in Belgrade, given the greater chances in the struggle for survival or enrichment that it provides. On the other hand, urban centers that did not have so much "luck" were left without most of the functions, not to mention the large number of rural settlements that have remained or will remain without people due to the insufficient attractiveness of agriculture. It is certain that these trends are normal, and that they follow certain phases of the development of modern society. What is painful for Serbia, and most of all dangerous, is that the differences are increasing - in Belgrade and several larger centers is the majority of the population, economic and management capacity and almost all finances, and in the rest (which cannot and must not be ignored) little of the above mentioned. There is a justified fear that Serbia as a whole, with all good intentions, will 
not be able to "function" even by defining functional urban areas and measures for their management, because scientifically speaking, most of its territory is not covered by such areas due to underdeveloped functions of urban centers. When it comes to the declarative goals of reducing development disparities through the process of decentralization, primarily the proposed regionalization, a very sensitive and current issue of borders always opens for Serbia - first of all states, then regions that are not yet precisely defined. Apart from the border, the issue of the competences of future regions (NUTS level 2) is also unclear, because a certain part of the political elite insists, precisely because of the sensitivity of the issue of regionalization, that these are statistical units. However, neither the competencies nor the means for performing those competencies are decentralized to them, nor is the policy of more balanced regional development pursued on the basis of them. In order for the concept of protection and sustainable use of the territory to come to life in sufficient scope, it is necessary to change the course from the neoliberal economic approach which deepened the already existing territorial differences in Serbia towards the approach of the state of social welfare of all its citizens.

The issue of a new administrative or planning regionalization was omitted in the new Spatial Plan. The issue of regionalization of Serbia has always been topical, politically sensitive and has been frequently discussed in recent years. Addressing the issue of balanced territorial development is a key goal of any regionalization. It seems that such a cautious attitude is the result of two views: the first, that it is neither the time nor the place (domain of the plan) to raise such a big political issue again, and the second, that previous efforts in that direction were partly an infantile attempt to reach some additional funds from the European Union if foreign factors allow it, and partly a clumsy and probably disastrous way to solve some backward issues of territorial autonomy, status, political electoral mathematics, etc. The issue of regionalization is, of course, closely related to the issue of decentralization. Everything leads to the conclusion that instead of some functional decentralization, real decentralization will be only declarative, because there is no indication that the state is ready to share a significant part of its revenues to cities and municipalities as local governments or districts - rather we are witnessing a classic model of reconcentration. The territories that can count on some funds are the city of Belgrade, because it already has them and Vojvodina which will receive (or keep) serious financial income if the proposed Statute is adopted by the National Assembly of the Republic of Serbia. This will make regional differences even more pronounced.

When it comes to regional spatial plans made for the territory of Serbia, the principle of sustainability has been consistently copied from the Spatial Plan of the Republic of Serbia, and through planning measures, where appropriate, incorporated into priority and long-term solutions. The question remains to what extent these solutions are implemented in practice. The most critical in this regard is the Spatial Plan for the Autonomous Province Kosovo and Metohija, where it is explicitly stated that .... spatial planning should be in the function of sustainable development (p. 104), but immediately afterwards, serious limitations due to which such the goal is extremely difficult to achieve are listed on 40 pages [10].Without exception, all regional plans indicate a highly unbalanced and polarized territorial development within the borders of the region: thus, the problem of uneven spatial development from the national to the regional and even local level, and such a situation in space has existed for a long time [11].

More broadly, in the European context, the political debate on territorial inequalities is visibly structured around the contrast between "metropolitan" and "non-metropolitan areas". The decline in direct state participation in defining explicit spatial policies is a 
trend in the EU, so that direct mechanisms of redistribution of money from richer regions to poorer ones have weakened [12]. At the same time, it seems that the European public is increasingly accepting social inequalities, so that the notions of the fight for social justice and against social inequalities are less and less heard. With reduced influence, European national authorities tend to help more "metropolitan" than underdeveloped areas. This is happening even in France, where after 50 years, Gravier's paradigm of Paris and the French desert has been abandoned. Beginning in 2005, when Paris was proclaimed as the national engine of development, large projects in the city began to be realized again and this process continues today [13]. It is clear to local actors in spatial development that little help can be expected "from above": if they hope for any development shift, local initiatives - "from below" - must be strengthened. Truth be told, France is a rich and spatially, well-equipped country. Accessibility to large cities is relatively efficient and fast enough: nevertheless, even in professional circles, there is a growing nostalgia for the good old days and strong state intervention in space, and DATAR has become something of a national legend. Maybe something in France will take a step back, but the experience is valuable for Serbia, with a too big Belgrade and a territory that is being equipped with infrastructure.

Speaking about the trend that the practice of spatial planning in Serbia "takes place as usual", it must be emphasized that there are several reasons for such a situation. It is not wrong to look for these reasons in the major socio-economic and political changes that took place in Serbia after 2000. Spatial planning has lost its significance after these and such changes, and that is a fact that almost all professional planners and urban planners find difficult to experience. As in other segments of social practice, radical changes have been introduced in spatial planning instead of gradual adjustment in accordance with real modest possibilities. The same thing happened in other countries that went through a postsocialist transition [14]. This has led to the dysfunction of the planning system and the reduction of the already high degree of disorder in space.

Today, the spatial plan in Serbia is done quickly and easily, because except formally, it does not oblige anyone [15]. The plan in Serbia today represents a labile balance between political (un)realism and pursuit of such a balance in space. The dangers of shortening the procedure are obvious - getting a permit at one counter, office for quick answers instead of expert control, replacing PR analysis, mimicry of public participation under the guise of higher interest (e.g. joining the EU or increasing the employment rate). Although weakened, the system maintained its internal balance in the first decade after the changes, because it took time to fully understand the new conditions. Hence a certain inertia, fueled on the one hand by the expected rapid entry of Serbia into the EU, and on the other hand by the inability of the authorities to constitute a new model of space management (remember that 20 years after the changes we still struggle with legalization and cadaster). Investor urbanism existed in full force even then and since then it has been a great headache for the professional community of planners.

The change in the internal balance of the planning system in favor of the Spatial Plans of the Special Purpose Area occurred gradually and almost imperceptibly. There was no key point of overthrow or change of the legal framework: simply the planning community, figuratively speaking, woke up one morning aware that the situation had changed. The reason that first comes to mind is that it is a natural thing: planning takes place in cycles and if one of them was completed around 2010, it was certain that there would be a certain flattening of activities [16]. However, the intensity of the activity did not subside, it only changed its focus. On the one hand, the enthusiasm for joining the EU and copying the 
demanding rules introduced by the Community, which it is implementing less and less, is preoccupied with its internal problems. As always, world and European trends have spilled over into our backyard: general confusion on a global scale has led to sobriety at home. Being in a new situation, unfettered by outside rules, the state has resorted to pragmatism, which is an expected and realistic procedure for experts. The pragmatism of the state in terms of planning and use of space is reflected in the fact that this time the state has precisely defined its interests in space, and through the instrument of Spatial Plans of the Special Purpose Area with elements of detailed elaboration found a legal mechanism to put planning, design, until the issuance of building permits control. The process was completely exposed by drafting and adopting the Spatial Plan of the Special Purpose Area for the so-called Belgrade Waterfront: a project for which an urban plan (under the jurisdiction of the city of Belgrade) in the old system would be sufficient, has been raised to the national level [17].

By taking the competencies of the city administration into its competence, the state has shown that it cares little for the local community - if it can do that in Belgrade, it can do it in the whole country. This led to a situation where the state, under the guise of national interest, reserves and manages space that is attractive to it for any reason, without any interference from the local community (which is left with land for which the state has not expressed interest). In this way, the state became the main economic investor: by neglecting the issue of social inequalities in space in practice, it set a bad example for the private initiative as well.

\section{CONCLUSION}

Every serious discussion on the territorial development of Serbia implies initiating, and every serious planning action means resolving a whole series of issues that directly or indirectly affect territorial development, because spatial planning is such - complex and multidisciplinary. Hence, this shortened content presentation of the current situation and perspective answers to the most important problem of today - inequality - is only one of the many dimensions of the development of Serbia. The statement that in this respect the spatial policy continues as before by many participants in the development of the Plan was perceived as the only possible one, given the overall economic over-indebtedness of the country, empty funds, creeping pace of European integration and other factors, as well as the obvious lack of real and continuous strategic action based on a balanced vision of the state of rich citizens - factors that in relation to the domain of the National Spatial Plan can be called external. In other words, there are not sufficient preconditions to talk about a balanced territorial development of Serbia.

There is neither the means nor the will to direct those funds properly and continuously. Hence, the real scenario of Serbia's territorial development in the coming period will be characterized by further deepening of regional differences (e.g. underdeveloped South and developed North, peripheral regions will find it difficult to cooperate with similar regions on the other side of neighboring countries, and political will to permanently resolve territorial issues will fluctuate around the following: the vassal status of the state, lack of money and political election calculations. In these three issues, the spatial planning profession can do little except declarative statements that no one can hear. Therefore, the likely epilogue of this discussion will be the realization of the idea of two Serbia, at least when it comes to territorial development. Spatial planning should reactivate the welfare state policy as its basic permanent professional goal. 


\section{REFERENCES}

[1] Ministry of Construction, Transport and Infrastructure. Report on the realization of the Spatial Plan of the Republic of Serbia and the state of spatial development 2018. Serbia, 1-114, 2019.(in Serbian)

[2] Krunic, N, Tosic, D., Gajic, A. Urban systems - contribution to the working version of the Study "Population, Settlements and Social Development", PPRS from 2021 to 2035, Serbia, 2020.(in Serbian)

[3] Tošić, D. Principles of regionalization. Faculty of Geography, Belgrade, Serbia, 1-249, 2012.

[4] Friedmann J. Regional Development Policy: A Case Study of Venezuela. Boston: M.I.T. Press, 1996.

[5] Statistical Office of the Republic of Serbia. Municipalities and regions in the Republic of Serbia. Serbia, 2019.

[6] Ministry of Construction, Transport and Infrastructure. Working version of the Draft Spatial Plan of the Republic of Serbia 2021-2035. Serbia, 2021.

[7] Government of Republic of Serbia. National Investment Program until 2025. Belgrade, Serbia, 2019.

[8] Dabović, T., Djordjević, D. Poledica, B. Radović, M., Jeftić, R. M. Compliance with social requirements for integrated local land use planning in Serbia, European Planning Studies, 2019.

[9] Nikitović, V., Bajat, B., Blagojević, D. Spatial patterns of recent demographic trends in Serbia (1961-2010). Geografie. 121(4), 521-543, 2016.

[10] Kosovo Spatial Plan 2010 - 2020+. Pristina, 2010.

[11] Đorđević D., Dabović T. System of spatial planning in Serbia: a critical overveiw. DELA 31, Oddelek za geografijo, Filozofska fakulteta Univerze v Ljubljani, Ljubljana, 143 - 157, 2009.

[12] Davezies L. La Republique et ses Territoires. La circulation invisible des richesses (Le Seuil, La Republique des Idees, Paris). 2008.

[13] 1. Desjardins X. Greater Paris and its Lessons for Metropolitan Strategic Planning. Town Planning Review 89 (1), 1-22, 2018.

[14] Thomas, M. Thinking about planning in the transitional countries of Central and Eastern Europe. International planning studies 3, pp. 321-333, 1998.

[15] Djordjevic, D., Dabovic, T., Zivak, N. Land use planning in a new context of spatial planning: a period of decline. Proceedings of the conference: Local self-government in planning and arranging space and settlements. Association of Spatial Planners of Serbia, University of Belgrade, Faculty of Geography, Republic Agency for Spatial Planning, Belgrade, 43-50, 2014.

[16] Nedović-Budić, Z, Đorđević, D., Dabović T. The Mornings After....Serbian Spatial Planning Legislation in Context. European Planning Studies 19, No.3, 429-455, 2011.

[17] Đorđević, D., Dabović, T. Bijelić, B., Poledica, B. Weakening of Spatial Planning System in Serbia - Age of Prevailing of Spatial Plans for Special Purpose Areas (2010-2020) (= Слабљење система просторног планирања у Србији - Доба превласти просторних планова подручја посебне намене (2010-2020). Гласник Српског Географског Друштва 100 (2) 129-160 (=Bulletin of the Serbian Geographical Society), Serbia, 2020. 